\title{
A reappraisal of Thecocoelurus daviesi (Dinosauria: Theropoda) from the Early Cretaceous of the Isle of Wight
}

\author{
Darren Naish and David M. Martill
}

\begin{abstract}
NAISH, D. \& MARTILL, D.M. 2002. A reappraisal of Thecocoelurus daviesi (Dinosauria: Theropoda) from the Early Cretaceous of the Isle of Wight. Proceedings of the Geologists' Association, 113, 23-30. An incomplete cervical vertebra of a theropod dinosaur from the Lower Cretaceous of the Isle of Wight, England, first described by Seeley in 1888 and made the type of Thecocoelurus daviesi, shows features unique to the oviraptorosaur-therizinosauroid clade of coelurosaurian theropods. It differs from the cervical vertebrae of therizinosauroids and closely resembles those of the caenagnathid oviraptorosaur Chirostenotes. If this identification is correct, this specimen is, with the exception of a problematical small femur and some Spanish eggshell fragments, Europe's first reported member of the oviraptorosaurtherizinosauroid clade and also one of the oldest representatives of the clade. Comparison of the specimen with the cervical vertebrae of other theropods indicates that it came from a large animal compared to most other oviraptorosaurs.
\end{abstract}

School of Earth and Environmental Sciences, University of Portsmouth, Portsmouth, P01 3QL, $U K$

\section{INTRODUCTION}

The Wessex Formation (Lower Cretaceous, Barremian) of the Isle of Wight, England (Fig. 1), yields a diverse Early Cretaceous dinosaur assemblage that includes hypsilophodontid, dryosaurid and iguanodontid ornithopods, polacanthid ankylosaurs, rare stegosaurs and marginocephalians and diplodocoid, brachiosaurid and titanosaurian sauropods (Martill \& Naish, 2001). The assemblage also includes several theropod taxa.
The Wessex Formation theropods are diverse and include large- and small-bodied taxa, many of which have highly convoluted systematic histories (Naish, 1999a; Naish et al., 2001). Baryonychid spinosauroids are represented by isolated teeth (Martill \& Hutt, 1996) whereas the allosauroid Neovenator salerii is represented by a nearly complete skeleton (Hutt et al., 1996). Coelurosaurs include the probable compsognathid Aristosuchus pusillus (Owen, 1876; Seeley, 1887a; Naish, 1999b), the problematic Calamosaurus

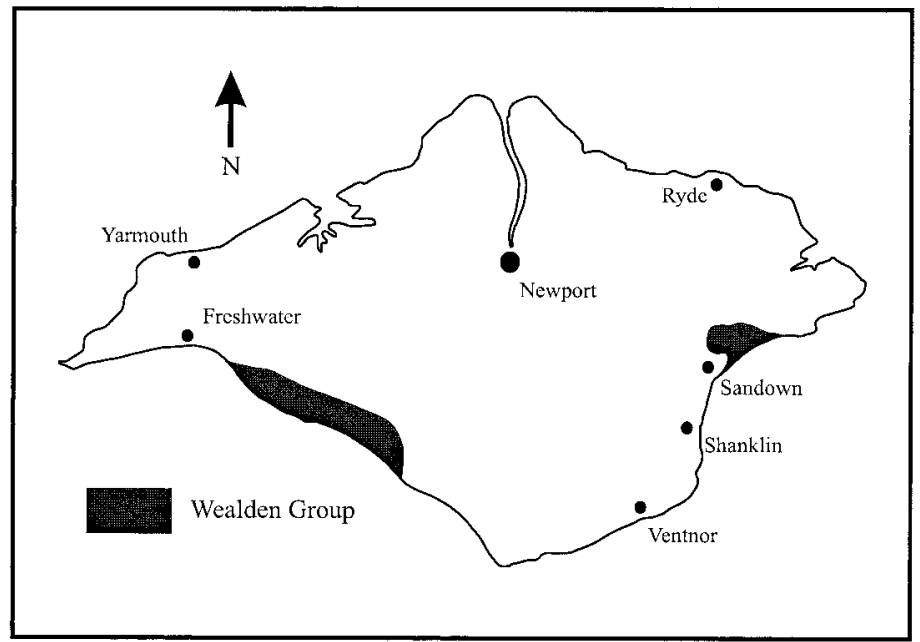

Fig. 1. Map of the Isle of Wight showing the outcrop of the Wessex Formation. The Rev. Fox collected most of his material from the outcrops of the southwest coast. 
foxii (Lydekker, 1889) and the basal tyrannosauroid Eotyrannus lengi (Hutt et al., 2001). Calamospondylus oweni, typically regarded as synonymous with $A$. pusillus (Norman, 1990; Insole \& Hutt, 1994; Kirkland et al., 1998), was named for a lost specimen that is not identical with the A. pusillus holotype (Fox in Anon., 1866; Blows, 1983; Naish, 1999a, b). Ornithodesmus cluniculus, based on the small sacrum BMNH R187 (Seeley, 1887b), has been compared with troodontid (Howse \& Milner, 1993) and dromaeosaurid coelurosaurs (Norell \& Makovicky, 1997), as well as with coelophysoids (Makovicky, 1995; Naish, 1999c).

Numerous previously unidentified theropod elements are also present. The incomplete cervical vertebra BMNH R181, the holotype of Thecocoelurus daviesi Seeley, has previously been regarded as an indeterminate 'coelurid' coelurosaur (Steel, 1970). A reappraisal of this specimen indicates that this is probably a member of the Oviraptorosauria, thereby adding a further theropod clade to the Wessex Formation assemblage and increasing the stratigraphical and geographical range of this clade.

The holotype of Thecocoelurus daviesi (BMNH R181) was discovered in the Wessex Formation in the late nineteenth century by the Rev. William Fox. Like most Early Cretaceous English small theropods, the taxon has a complex nomenclatural history and was originally described as Thecospondylus daviesi (Seeley, 1888). Seeley's reasons for referral of the specimen to Thecospondylus, a genus erected on the natural cast of an indeterminate sacrum from the Hastings Group of Southborough, Kent (Seeley, 1882), were a similar degree of elongation and lateral compression of the centra, and the thin nature of the bony wall.

BMNH R291, the type specimen for Thecospondylus horneri, is a $600 \mathrm{~mm}$ long natural internal cast of a sacrum. Seeley (1882) thought that it came from an animal similar to the sauropod Ornithopsis. Consequently, Lydekker (1888a) listed T. horneri under incertae sedis (but immediately after Ornithopsis) within his Sauropoda section and also regarded it as a sauropod in Lydekker (1888b). Huene (1926) was unsure about the identity of T. horneri and suggested that it was from an ornithopod. Clearly, T. horneri should be regarded a nomen dubium. At $600 \mathrm{~mm}$ long, the cast must have come from a large dinosaur (Norman, 1990; Naish et al., 2001) and not a small one as often assumed. It does not appear to be an informative specimen and any suggested identification is speculative.

Huene (1923) therefore recognized that referral of Thecocoelurus daviesi to Thecospondylus was unsatisfactory and proposed the new genus Thecocoelurus. We follow Huene (1923) in regarding it as misleading to include BMNH R181 within Thecospondylus. However, as BMNH R181 lacks diagnostic characters, Thecocoelurus daviesi should be regarded as a nomen dubium. Despite the lack of diagnostic characters for specific level definition, $T$. daviesi exhibits a number of informative features.
Institutional abbreviations BMNH, Natural History Museum, London; MIWG, Museum of Isle of Wight Geology, Sandown, Isle of Wight.

\section{SYSTEMATIC PALAEONTOLOGY}

Dinosauria Owen, 1842

Saurischia Seeley, 1888

Theropoda Marsh, 1881

Tetanurae Gauthier, 1986

Coelurosauria Huene, 1914

Oviraptorosauria Barsbold, 1976

Linnean binomial: Thecocoelurus daviesi (Seeley, 1888)

Holotype. Incomplete cranial cervical vertebra BMNH R181 (Figs 2-4).

Locality. Isle of Wight (Seeley, 1888).

Geological horizon and age. Most probably from Wessex Formation. Lower Cretaceous: Barremian.

\section{DESCRIPTION AND COMPARISONS}

Seeley's (1888) description is detailed and comprehensive and we therefore avoid repeating his observations. Instead, we focus on the characters that have either not previously been described, or are of importance in determining the phylogenetic position of this specimen.

The cranial articulatory face of the centrum is subrectangular and slightly concave. It is wider than it is tall (17 mm wide, $15 \mathrm{~mm}$ tall) and thus demonstrates coelurosaurian affinities (Gauthier, 1986). The neural canal is higher than wide (10 $\mathrm{mm}$ tall, $9.5 \mathrm{~mm}$ wide) and has elliptical cranial pedicular fossae located on either side (Fig. 3C). Presence of such fossae is variable within Theropoda and, following Frankfurt \& Chiappe (1999), their presence was coded for in the phylogenetic analysis (character 1). In lateral view, the vertebrae when complete would have been relatively long and low. Because some theropods possess relatively short, tall cervical vertebrae, this character was also coded for in the analysis (character 2).

Dorsally, the neural spine is hardly discernible and forms the apex to a dorsal roof of bone that extends over the neural arch and curves ventrolaterally on both sides, being more complete on the right side than the left (Fig. 2). On the left side the missing part of the roof exposes the laminae contacting the diapophysis. Prominence of the neural spine is also variable within theropods, being conspicuously reduced in oviraptorosaurs and some other coelurosaur groups. Following Frankfurt \& Chiappe (1999), we included relative neural spine height in the analysis (character 3 ).

The prezygapophyses are broken but are supported by a ventrolateral extension of the bony lamina that forms the lateral wall to the interspinous ligament pit. The bases of the prezygapophyses are widely spaced in dorsal view (Fig. 2D). Frankfurt \& Chiappe (1999) coded for the presence of a V-shaped or U-shaped 

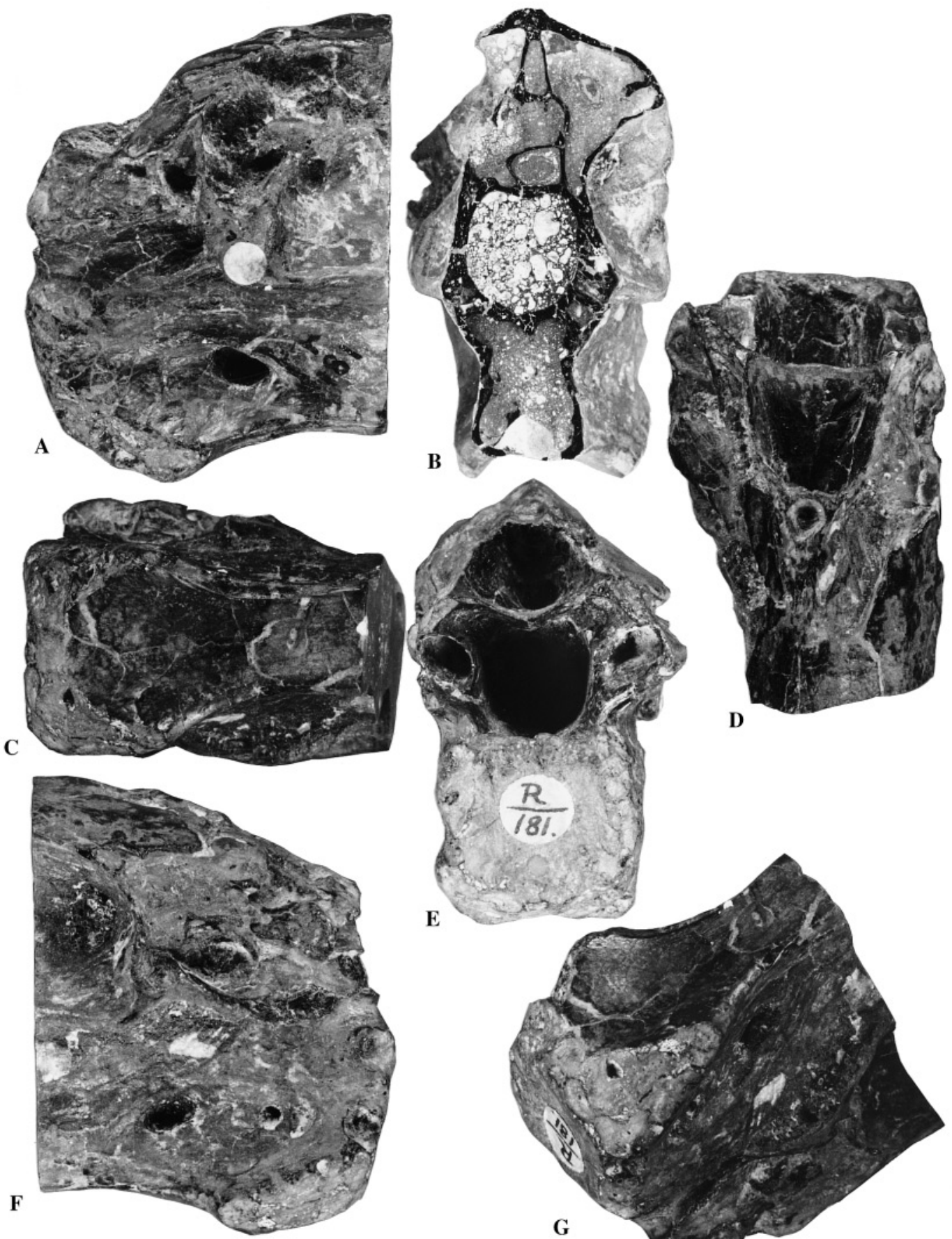

E

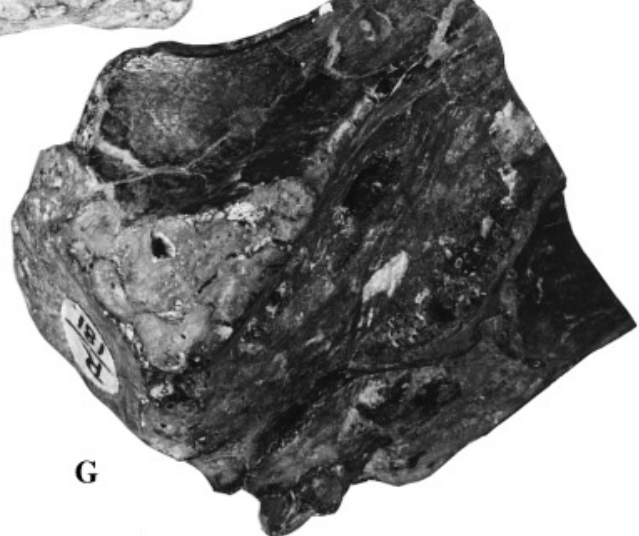

Fig. 2. Thecocoelurus daviesi (Seeley, 1888) BMNH R181 from the Wessex Formation (Lower Cretaceous) of the Isle of Wight: (A) left lateral view; (B) caudal view; (C) ventral view; (D) dorsal view; (E) cranial view; (F) right lateral view; (G) oblique right ventrolateral view. All $\times 1.4$. 

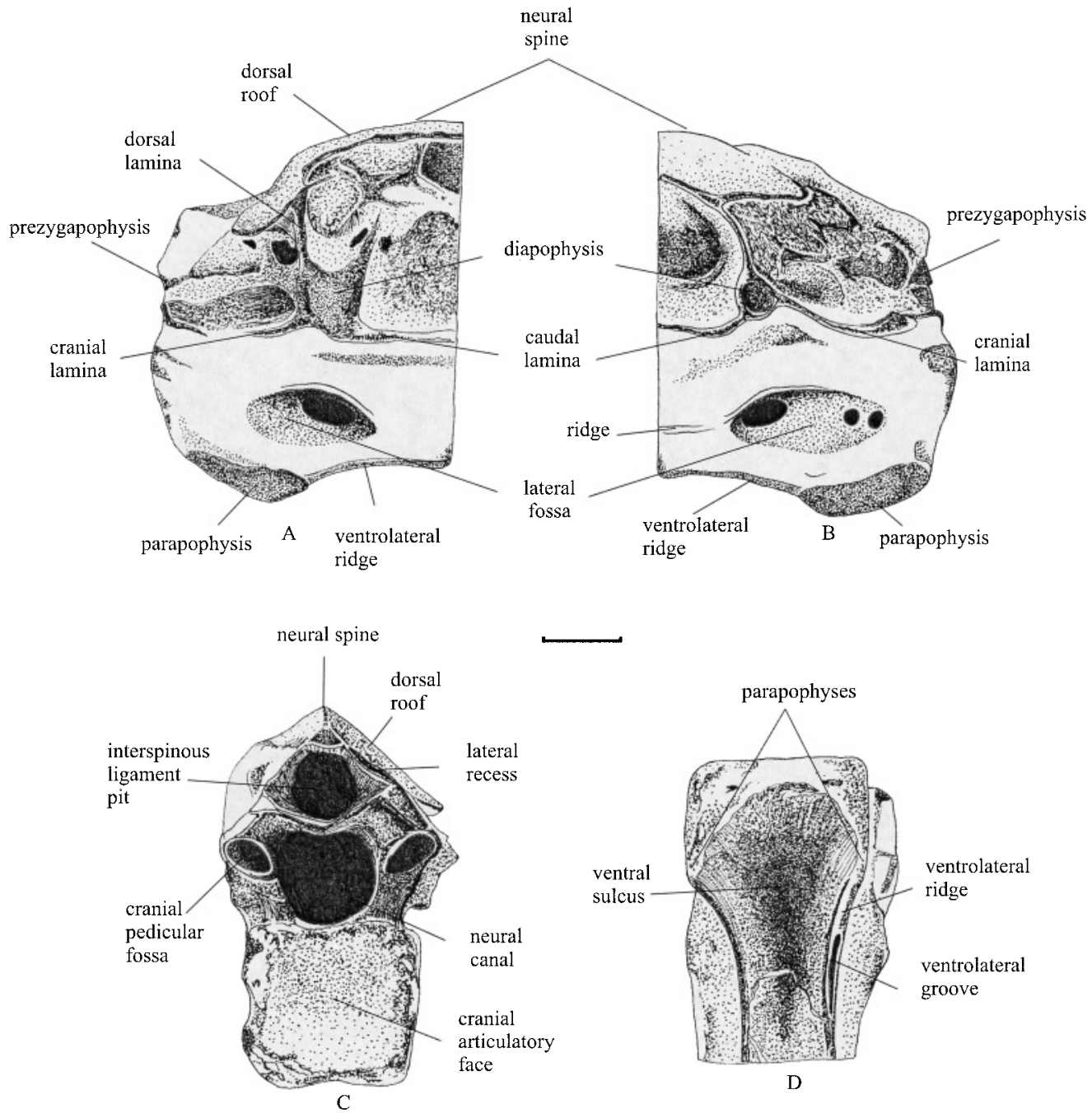

Fig. 3. Illustrations of cervical vertebra BMNH R181: (A) left lateral view; (B) right lateral view; (C) cranial view; (D) ventral view. Scale bar $10 \mathrm{~mm}$.

space between theropod prezygapophyses, and regarded the U-shaped space as the derived condition. We included this character in the analysis (character 10). However, due to breakage the character state present in BMNH R181 could not be interpreted unambiguously and was therefore coded '?'.

In lateral view, the parapophyses are located on the cranioventral corners of the centrum (Figs 2A, 3A). The diapophyses are poorly developed but appear to project horizontally from the base of the neural arch. Frankfurt \& Chiappe (1999) coded the presence of horizontally projecting diapophyses (where the caudal border of the diapophyses nearly forms a right angle with the centrum in dorsal view) as a derived character of oviraptorosaurs and some other coelurosaurian taxa. It was included in our analysis (character 9).
Because the polarity of this condition was unclear in BMNH R181, it was coded in the analysis as '?'.

On the caudoventral part of the centrum's right side there is a low horizontal ridge: this is absent from the centrum's left side (Figs 3A, 3B). Cranial to the ridge there is a shallow, elliptical lateral fossa overhung by a horizontal shelf. Within this fossa there are three foramina: a larger elliptical one at the caudal end and two smaller, rounded ones located next to each other, separated by a very narrow bridge of bone, at the cranial end. Seeley (1888) did not note or figure the two smaller foramina. The left side of the centrum exhibits the same elliptical lateral fossa with its dorsal shelf but the two smaller cranial foramina are absent.

Ventrally, the ventrolateral margins that define the edges of the centrum's ventral surface curve medially 


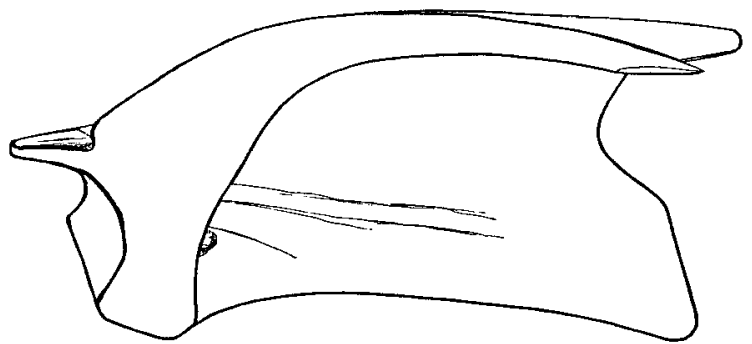

Fig. 4. Seeley's (1888) attempt to reconstruct BMNH R181 when complete.

as they approach mid-way along the centrum, creating an hourglass-like shape and a shallow ventral sulcus (Fig. 3D). Presence or absence of the ventral sulcus delimited by sharp ridges ventrolaterally was included in the analysis (character 8). The ventrolateral ridges merge cranially with the parapophyses. The ventrolateral ridge on the left side has an elongate ventrolateral groove that runs craniocaudally for much of the length of the ridge (Figs 2C, 3D). This groove is absent from the right side where the ventrolateral ridge is smoothly rounded. Although Seeley (1888) described this structure, it is missing from the accompanying figures. Carotid processes are not present as they are in troodontids and avians (Makovicky, 1995). Presence or absence of carotid processes was included in the analysis (character 4).

A notable feature of BMNH R181 is its asymmetry. Marked asymmetry in the skeletons of coelurosaurian theropods has been noted before: Martill et al. (2000) described prominent asymmetry in the pelvis of the small Santana Formation coelurosaur SMNK 2349 PAL. The presence of a ridge and two small foramina on the right side of the centrum in BMNH R181, and a groove on the left ventrolateral ridge, suggest that these features might be subject to individual variation and as such little emphasis should be placed on their taxonomic value.

\section{MORPHOLOGICAL COMPARISONS}

The holotype vertebra of Thecocoelurus daviesi is small and incomplete, being $39 \mathrm{~mm}$ long and lacking its caudal half. The caudal end has been sectioned and polished, revealing the internal structure of the pleurocoels (Fig. 2B). The presence of pleurocoels on the centra and of a relatively elongate centrum demonstrate allocation to Saurischia. Seeley (1888) provided a reconstruction of the complete vertebra and this has a length of approximately $90 \mathrm{~mm}$ (Fig. 4). Based on comparisons with other theropod vertebrae, we feel that this is too long and a more reasonable length is $70 \mathrm{~mm}$. Comparison with other theropod cervical vertebrae suggests a total length of around $5 \mathrm{~m}$ for this animal.
On the basis of simple morphological comparison, we note that BMNH R181 is most similar to the caudal cervical vertebra of Chirostenotes pergracilis from the Upper Cretaceous Horseshoe Canyon Formation of Alberta (Sues, 1997). The ventral hourglass shape with its shallow, broad sulcus and raised lateral margins that join the parapophyses (see Fig. 3D) are autapomorphic for the therizinosauroid-oviraptorosaur clade (we use Oviraptorosauria here in the sense of Makovicky \& Sues (1998) and Padian et al. (1999) i.e. including Caenagnathidae, Oviraptoridae and probably Microvenator - and do not follow Sereno's (1998) more inclusive use of the name). Aside from unambiguous members of the oviraptorosaurtherizinosauroid clade, this morphology is also seen in the isolated Argentinian vertebra described by Frankfurt \& Chiappe (1999) and the Quarry 9 vertebra from the Morrison Formation (Makovicky, 1997). Both of these vertebrae have been tentatively referred to this clade (Frankfurt \& Chiappe, 1999). Therizinosauroid cervical vertebrae have slit-shaped central pneumatic foramina and more robust neural spines than oviraptorosaurs (Makovicky, 1995): Thecocoelurus daviesi is therefore probably not a therizinosauroid as its pneumatic foramina are rounded and its neural spine is not robust. We therefore consider that Thecocoelurus daviesi most probably represents an oviraptorosaur.

\section{PHYLOGENETIC ANALYSIS}

In a previous study on an oviraptorosaur-like isolated cervical vertebra from the Upper Cretaceous Lecho Formation of Argentina, Frankfurt \& Chiappe (1999) tested the affinities of their specimen by including it within a phylogenetic analysis of theropod cervical vertebrae. As we were also interested in testing the phylogenetic affinities of a possible oviraptorosaurian specimen, we incorporated data from Thecocoelurus daviesi into the data matrix of Frankfurt \& Chiappe (1999) and re-ran the analysis. Our list of characters is thus the same as that of Frankfurt \& Chiappe (1999) though we added one extra character (character 11): presence of apneumatic, camerate or camellate interior to the centrum (Britt, 1993). The analysis was performed in NONA 1.6, using the Empezar and Max tree searching options. For our character codings of BMNH R181, see the Appendix.

Our study generated 15 most parsimonious trees. As in Frankfurt \& Chiappe's (1999) study, our cladogram should not be interpreted as an attempt to resolve the phylogeny of the included taxa, but as a test of our hypothesis that BMNH R181 is an oviraptorosaur. In all 15 trees, BMNH R181 was included within the oviraptorosaur-therizinosauroid clade. It occupied all possible tree positions within this clade though, as stated earlier, we note that the specimen most closely resembles caenagnathid oviraptorosaurs and is unlikely to be a therizinosauroid. The tree in Figure 5 


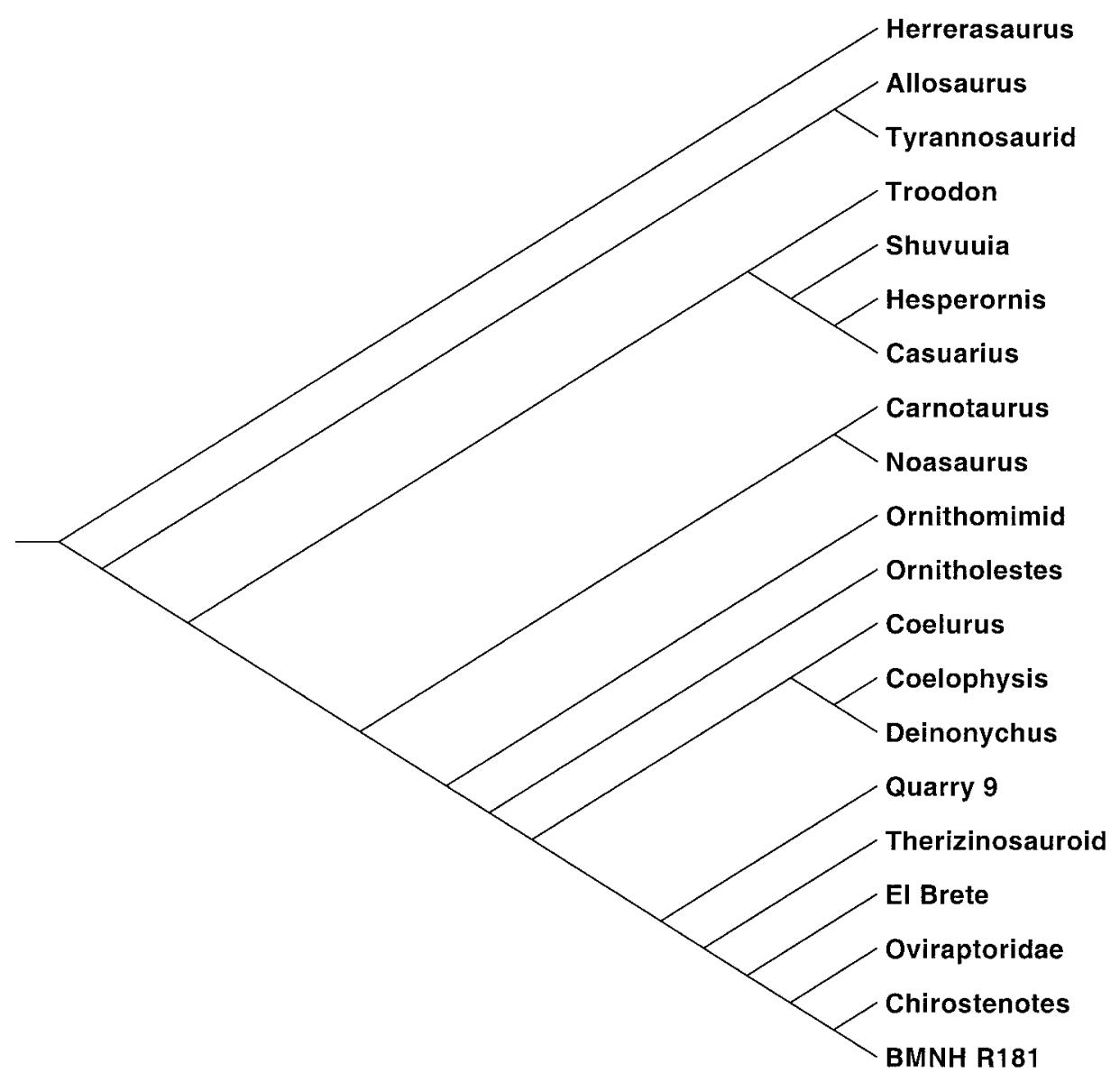

Fig. 5. Cladogram chosen from 15 most parsimonious trees (consistency index: 0.70; retention index: 0.83 ; length: 17 steps) and based on characters from the data matrix of Frankfurt \& Chiappe (1999). This cladogram does not represent an analysis of the ingroup taxa but is a test of BMNH R181's position within the theropod tree.

reflects this view. The phylogenetic analysis therefore supports our suggestion that Thecocoelurus daviesi is an oviraptorosaur.

The ventral sulcus delimited by ventrolaterally directed ridges was an unambiguous synapomorphy of the oviraptorosaur-therizinosauroid clade. Presence of a U-shaped space between the prezygapophyses was an ambiguous synapomorphy of this clade.

\section{DISCUSSION}

Recognition of Thecocoelurus daviesi as an oviraptorosaur extends the geographical range of this group to Europe. Similarities in the dinosaur assemblage between the Wessex Formation and some of the Lower Cretaceous strata of North America (Ostrom, 1970; Kirkland et al., 1993), and the presence of the basal oviraptorosaur Microvenator celer in the Cloverly Formation of Montana (Makovicky \& Sues, 1998), had allowed the presence of oviraptorosaurs in the
Early Cretaceous of Europe to be predicted (Naish, 2000).

Identification of a Wessex Formation specimen as an oviraptorosaur suggests that further material of this group might be present in the Lower Cretaceous of Europe. Naish (2000) described a small theropod femur (MIWG 6214) from the Wessex Formation with similarities to the holotype femur of Microvenator celer, though the identity of the specimen remained unresolved. Ruiz-Omeñaca et al. (1999) referred to unpublished work by Amo (1998) on dinosaur eggshell from the Barremian of northeastern Spain. Amo (1998) suggested that Spanish eggshell referred to the oofamily Elongatoolithidae may represent oviraptorosaurs (see Norell et al., 1994; Dong \& Currie, 1996). There are no other records of the Oviraptorosauria in Europe.

The Barremian age of the Wessex Formation (Allen \& Wimbledon, 1991) makes Thecocoelurus daviesi one of the earliest members of this group. Other possible 
early records of the oviraptorosaur-therizinosauroid clade are from the Late Jurassic Morrison Formation of Wyoming (Makovicky, 1997), the Valanginian or Hauterivian of Japan (Manabe et al., 2000) and the Early Jurassic of China (Zhao \& Xu, 1998; Xu et al., 2001). As noted by De Klerk et al. (2000), the latter record indicates that these theropods could have been globally distributed and perhaps owe their later distribution to vicariance.

\section{CONCLUSIONS}

- The incomplete cervical vertebra BMNH R181, the holotype of Thecocoelurus daviesi, exhibits a number of features unique to oviraptorosaurian coelurosaurs and probably represents an oviraptorosaur. This conclusion is supported by parsimony analysis - in all most parsimonious trees BMNH R181 was found to be a member of the oviraptorosaurtherizinosauroid clade.

- While the specimen strongly resembles the cervical vertebrae of the oviraptorosaur Chirostenotes, it lacks any unique features and cannot be diagnosed as a distinct taxon. The binomial name erected for the specimen, Thecocoelurus daviesi, should thus be regarded as a nomen dubium.

- Reconstruction suggests that the complete vertebra was about $70 \mathrm{~mm}$ long. Comparison with other theropods suggests that total body length may therefore have been around $5 \mathrm{~m}$ long. This is large for an oviraptorosaur, most of which were less than $3 \mathrm{~m}$ long (Paul, 1988). The specimen exhibits a number of asymmetrical features.

- The specimen is one of the oldest reported members of the oviraptorosaur-therizinosauroid clade and one of only a few possible records of the group from Europe.

\section{ACKNOWLEDGEMENTS}

For access to specimens we thank Sandra Chapman and Angela Milner. Hans-Dieter Sues and Pete Makovicky initially suggested that BMNH R181 was worthy of re-examination and provided helpful discussion. Jim Kirkland and three anonymous reviewers provided comments that greatly improved the manuscript. Alberto Vasconcellos provided helpful discussion of the phylogenetic analysis. Bob Loveridge and Stig Walsh kindly assisted with the illustrations.

\section{APPENDIX}

\section{Character scores for BMNH R181}

Character scores for BMNH R181 for character matrix of Frankfurt \& Chiappe (1999), with character 11 added (see text).

10100?01???

\section{REFERENCES}

Allen, P. \& Wimbledon, W.A. 1991. Correlation of NW European Purbeck-Wealden (nonmarine Lower Cretaceous) as seen from the English type-areas. Cretaceous Research, 12, 511-526.

Amo, O. 1998. Fragmentos de cáscara de huevo de vertebrados del Cretácico Inferior de Galve (Teruel). Tesis de Licenciatura, Universidad de Zaragoza.

Anon, 1866. Another new Wealden reptile. The Athenaeum, 2014, 740 .

Barsbold, R. 1976. On a new Late Cretaceous family of small theropods (Oviraptoridae fam. n.) of Mongolia. Doklady Akademi Nauk SSSR, 226, 685-688.

Blows, W.T. 1983. William Fox (1813-1881), a neglected dinosaur collector of the Isle of Wight. Archives of Natural History, 11, 299-313.

Britt, B. 1993. Pneumatic postcranial bones in dinosaurs and other archosaurs. $\mathrm{PhD}$ thesis, University of Calgary, Alberta.

De Klerk, W., Forster, C.A., Sampson, S.D., Chinsamy, A. \& Ross, C.F. 2000. A new coelurosaurian dinosaur from the Early Cretaceous of South Africa. Journal of Vertebrate Paleontology, 20, 324-332.

Dong, Z.-M. \& Currie, P.J. 1996. On the discovery of an oviraptorid skeleton on a nest of eggs at Bayan Mandahu, Inner Mongolia, People's Republic of China. Canadian Journal of Earth Sciences, 33, 631-636.

Frankfurt, N.G. \& Chiappe, L.M. 1999. A possible oviraptorosaur from the Late Cretaceous of northwestern Argentina. Journal of Vertebrate Paleontology, 19, $101-105$
Gauthier, J. 1986. Saurischian monophyly and the origin of birds. Memoirs of the Californian Academy of Science, $\mathbf{8}$, $1-55$.

Howse, S.C.B. \& Milner, A.R. 1993. Ornithodesmus - a maniraptoran theropod dinosaur from the Lower Cretaceous of the Isle of Wight, England. Palaeontology, 36, 425-437.

Huene, F. von. 1914. Das natürliche System der Saurischia. Zentralblatt für Mineralogie und Paläontologie B, 1914, 154-158.

Huene, F. von. 1923. Carnivorous Saurischia in Europe since the Triassic. Bulletin of the Geological Society of America, 34, 449-458.

Huene, F. von. 1926. On several known and unknown reptiles of the Order Saurischia from England and France. Annals and Magazine of Natural History, Series 9, 17, 473-489.

Hutt, S., Martill, D.M. \& Barker, M.J. 1996. The first European allosaurid dinosaur. Neues Jahrbuch für Geologie und Paläontologie, Monatshefte, 1996, 635-644.

Hutt, S., Naish, D., Martill, D.M., Barker, M.J. \& Newbery, P. 2001. A preliminary account of a new tyrannosauroid theropod from the Wessex Formation (Early Cretaceous) of southern England. Cretaceous Research, 22, 227-242.

Insole, A.N. \& Hutt, S. 1994. The palaeoecology of the dinosaurs of the Wessex Formation (Wealden Group, Early Cretaceous), Isle of Wight, Southern England. Zoological Journal of the Linnean Society, 112, 197-215.

Kirkland, J.I., Gaston, R. \& Burge, D. 1993. A large dromaeosaur (Theropoda) from the Lower Cretaceous of eastern Utah. Hunteria, 2, 10, 1-16. 
Kirkland, J.I., Britt, B.B., Whittle, C.H., Madsen, S.K. \& Burge, D.L. 1998. A small coelurosaurian theropod from the Yellow Cat Member of the Cedar Mountain Formation (Lower Cretaceous, Barremian) of eastern Utah. New Mexico Museum of Natural History and Science Bulletin, 14, 239-248.

Lydekker, R. 1888a. Catalogue of the fossil Reptilia and Amphibia in the British Museum (Natural History). Part 1, Ornithosauria, Crocodylia, Dinosauria, Squamata, Rhynchocephalia, and Proterosauria. British Museum (Natural History), London.

Lydekker, R. 1888b. Note on a new Wealden iguanodont and other dinosaurs. Quarterly Journal of the Geological Society of London, 44, 46-60.

Lydekker, R. 1889. On a coeluroid dinosaur from the Wealden. Geological Magazine, 6, 119-121.

Makovicky, P.J. 1995. Phylogenetic aspects of the vertebral morphology of Coelurosauria (Dinosauria: Theropoda). MSc thesis, University of Copenhagen.

Makovicky, P.J. 1997. A new small theropod from the Morrison Formation of Como Bluff, Wyoming. Journal of Vertebrate Paleontology, 17, 755-757.

Makovicky, P.J. \& Sues, H.-D. 1998. Anatomy and phylogenetic relationships of the theropod dinosaur Microvenator celer from the Lower Cretaceous of Montana. American Museum Novitates, 3240, 1-27.

Manabe, M., Barrett, P.M. \& Isaji, S. 2000. A refugium for relicts? Nature, 404, 953

Marsh, O.C. 1881. Principal characters of American Jurassic dinosaurs. Pt. V. American Journal of Science (series 3), 21, 417-423.

Martill, D.M. \& Hutt, S. 1996. Possible baryonychid dinosaur teeth from the Wessex Formation (Lower Cretaceous, Barremian) of the Isle of Wight, England. Proceedings of the Geologists' Association, 107, 81-84.

Martill, D.M. \& Naish, D. 2001. Dinosaurs of the Isle of Wight. The Palaeontological Association, London.

Martill, D.M., Frey, E., Sues, H.-D. \& Cruickshank, R.I. 2000. Skeletal remains of a small theropod dinosaur with associated soft structures from the Lower Cretaceous Santana Formation of northeastern Brazil. Canadian Journal of Earth Sciences, 37, 891-900.

Naish, D. 1999a. Studies on Wealden Group theropods - an investigation into the historical taxonomy and phylogenetic affinities of new and previously neglected specimens. MPhil thesis, University of Portsmouth.

Naish, D. 1999b. Fox, Owen and the small Wealden theropods Calamospondylus and Aristosuchus. Journal of Vertebrate Paleontology, 19, suppl. 3, 66A.

Naish, D. 1999c. Theropod dinosaur diversity and palaeobiology in the Wealden Group (Early Cretaceous) of England: evidence from a previously undescribed tibia. Geologie en Mijnbouw, 78, 367-373.

Naish, D. 2000. A small, unusual theropod (Dinosauria) femur from the Wealden Group (Lower Cretaceous) of the Isle of Wight, England. Neues Jahrbuch für Geologie und Paläontologie, Monatshefte, 2000, 217-234.

Naish, D., Hutt, S. \& Martill, D.M. 2001. Saurischian dinosaurs 2: Theropods. In (Martill, D.M. \& Naish, D.; eds) Dinosaurs of the Isle of Wight. The Palaeontological Association, London, 242-309.

Norell, M.A. \& Makovicky, P.J. 1997. Important features of the dromaeosaur skeleton: information from a new specimen. American Museum Novitates, 3215, 1-28.
Norell, M.A., Clark, J.M. \& Dashzeveg, D. et al. 1994. A theropod dinosaur embryo and the affinities of the Flaming Cliffs dinosaur eggs. Science, 266, 779-782.

Norman, D.B. 1990. Problematic Theropoda: 'Coelurosauria'. In (Weishampel, D.B., Dodson, P. \& Osmólska, H.; eds) The Dinosauria. University of California Press, Berkeley, 280-305.

Ostrom, J. 1970. Stratigraphy and paleontology of the Cloverly Formation (Lower Cretaceous) of the Bighorn Basin area, Wyoming and Montana. Peabody Museum of Natural History Bulletin, 35, 1-234.

Owen, R. 1842. Report on British fossil reptiles. Report of the British Association for the Advancement of Science, 11, 60-204.

Owen, R. 1876. Monograph of the fossil Reptilia of the Wealden and Purbeck Formations. Supplement 7. Crocodilia (Poikilopleuron), Dinosauria (Chondrosteosaurus). Palaeontographical Society Monograph, 30, 1-7.

Padian, K., Hutchinson, J.R. \& Holtz, T.R. 1999. Phylogenetic definitions and nomenclature of the major taxonomic categories of the carnivorous Dinosauria (Theropoda). Journal of Vertebrate Paleontology, 19, 69-80.

Paul, G.S. 1988. Predatory Dinosaurs of the World. Simon \& Schuster, New York.

Ruiz-Omenaca, J.I., Cuenca-Bescós, G. \& Canudo, J.I. 1999. Dinosaur remains in the Barremian (Lower Cretaceous) of the Teruel Province (Iberian Chain, NE Spain). In (Canudo, J.I. \& Cuenca-Bescós, G.; eds) IV European Workshop of Vertebrate Palaeontology, Programme and Abstracts. Universidad de Zaragoza 81-82.

Seeley, H.G. 1882. On Thecospondylus horneri, a new dinosaur from the Hastings Sand, indicated by the sacrum and the neural canal of the sacral region. Geological Magazine, 9, 378.

Seeley, H.G. 1887a. On Aristosuchus pusillus, Ow., being further notes on the fossils described by Sir R. Owen as Poikilopleuron pusillus, Ow. Geological Magazine, 47, 234-235.

Seeley, H.G. 1887b. On a sacrum apparently indicating a new type of bird, Ornithodesmus cluniculus Seeley from the Wealden of Brook. Quarterly Journal of the Geological Society of London, 43, 206-211.

Seeley, H.G. 1888. On Thecospondylus daviesi (Seeley), with some remarks on the classification of the Dinosauria. Quarterly Journal of the Geological Society, London, 44, 79-86.

Sereno, P.C. 1998. A rationale for phylogenetic definitions, with application to the higher-level taxonomy of Dinosauria. Neues Jahrbuch für Geologie und Paläontologie, Abhandlungen, 20, 41-83.

Steel, R. 1970. Encyclopedia of Paleoherpetology, Part 14: Saurischia. Gustav Fischer Verlag, Stuttgart.

Sues, H.-D. 1997. On Chirostenotes, a Late Cretaceous oviraptorosaur (Dinosauria: Theropoda) from western North America. Journal of Vertebrate Paleontology, 17, 698-716.

Xu, X., Zhao, X. \& Clark, J.M. 2001. A new therizinosaur from the lower Jurassic lower Lufeng Formation of Yunnan, China. Journal of Vertebrate Paleontology, 21, 477-483.

Zhao, X.-J. \& Xu, X. 1998. The oldest coelurosaurian. Nature, 394, 234-235. 